\title{
SELECTED ASPECTS OF PERFORMANCE MANAGEMENT AS A COMPONENT OF THE CONTEMPORARY MANAGEMENT OF BUSINESSES
}

\author{
Dagmar Burdová
}

\section{Klíčová slova:}

Efektivita, management, manažer, podnik, procesy, řízení pracovního výkonu, strategie, tým, výkony

\section{Key words:}

Effectiveness, management, manager, company, processes, performance management, strategy, team, performance

\begin{abstract}
Abstrakt
Článek se zabývá aktuálním tématem řízení pracovního výkonu, jež je bezesporu možné teoreticky definovat za nejdůležitější absolutní podmínkou úspěšného podniku. V současných neustále se měnících podmínkách podnikatelského prostředí jsou manažeři velmi často považováni za rozhodující činitele v prostředí řízení podniků. V článku je vyzdvižena role manažerů $\mathrm{v}$ oblasti řízení efektivnosti a výkonu podniků prostřednictvím řízení pracovního výkonu týmů a jednotlivců a zároveň nejdůležitější požadavky na úspěšné manažery $\mathrm{v}$ současném rychle se měnícím turbulentním podnikatelském prostředí. Celkově je pak vyzdvižena důležitost měkkých faktorů řízení pracovního výkonu jakožto jedna $\mathrm{z}$ nejdůležitějších podmínek jeho úspěšné implementace. Cílem tohoto článku je popsat teoretické východiska performance managementu a na základě metody dlouhodobého pozorování definovat vlastní závěry $\mathrm{v}$ oblasti bariér jeho zavádění a soubor opatření pro úspěšnou implementaci. V článku jsou využity praktické zkušenosti z oblasti podnikového řízení zaměřeného na pracovní výkon.
\end{abstract}

\begin{abstract}
The article focuses on performance management - a current topic widely discussed and one that can be indisputably theoretically defined as the single most important condition for a company to operate successfully. With the ever-changing business environment of today, managers are very often considered to be the decisive factors within a company's management. The article emphasizes the role of managers in the areas of performance and effectiveness in the company by managing the performance of teams and individuals. Other key points of the article are outlining the most important requirements of successful managers in today's quickly changing and turbulent business environment. The importance of soft factors in performance management is underlined as one of the most important conditions of its successful implementation. The aim of this article is to describe the theoretical grounds of performance management and, based on the method of long-term observation, define my own conclusions in the area of barriers to its introduction and outline a set of measures for its successful implementation. Practical experience from the domain of company management focused on performance has been utilised in this article.
\end{abstract}

\section{Introduction}

The most current managerial approaches are closely connected to personal management. In some cases it is very difficult to clearly define the area they primarily belong in. - Is it general 
or personal management? As well as many other approaches ${ }^{1}$, the performance approach is very important for management as it represents one part of management which has no strictly defined restrictions. It is generally acknowledged that only performance-focused companies can compete in the complex globalization world of today; even at that there are still major companies that face substantial problems. The Insolvency register shows a year on year growth in the numbers of insolvency proposals of companies - harsh financial conditions result in companies going through insolvency. The companies are not only facing these problems due to faulty financial management, i.e. liquidity and indebtedness, but also due to a low performance level which is one of primary causes of financial problems. The aim of this article is: to describe the basic prerequisites of the soft factors of the performance approach based on the uniqueness of managers as the main actor in company management; to present the potential challenges of this approach and to set basic recommendations for its successful implementation. Together with the other current managerial approaches, it presents a unique mixture of approaches needed to maintain effectiveness in companies.

\section{Performance management}

Performance management is one of the most basic elements in company management. In connection to the basic function of a company and entrepreneurship ${ }^{2}$, management is focused on performance. Nonetheless, performance management cannot be taken as the simple management of performance, Veber [17] defines it as a sum of management recommendations with the aim to enhance performance (effectiveness, productivity). Such an approach to managerial activities uses the intention to improve the dynamics in the development of the managed company as the common denominator. The key point of output is then the creation of new entrepreneurship conceptions, new managerial approaches or methodological manuals that can be used within various managerial activities. Features of performance management that cannot be replaced under any conditions are the key performance indicators (KPI) which gradually direct the companies towards the expected targets and define responsibilities of individual team leaders and team members.

\section{Managerial approaches to enhance the performance of a company}

Most of the current managerial approaches focus on enhancing company effectiveness. When speaking about process management, change management, risk management, balancescorecard $^{3}$ or kaizen methods, we always have to consider the overall intention of implementing such new approaches into the company management which will undoubtedly create a unique management system to enhance effectiveness and thus enhance the performance of the company. An increase in performance can be characterized as the cornerstone of building a successful company. Nowadays companies very often try

\footnotetext{
${ }^{1}$ Other current managerial approaches are namely the strategic approach, the carefulness approach, the systemic approach and the process approach.

2 According to $\$ 2$ of the Business code, entrepreneurship is a constant independent activity performed independently by the entrepreneur using his/her own name and taking responsibility in order to gain profit. From this we can easily deduct that if performance is one of the most important prerequisites for a company to gain profit, the performance management is de facto stated within the definition itself of entrepreneurship.

3 A Balanced Scorecard is a set of balanced indicators where financial indicators of performance in the past and indicators of new moving forces for the future performance are combined. A Balanced Scorecard should transform the mission and strategy of a company to tangible plans and indicators. It starts with the top management transferring the strategies of the company into specific strategic targets. More Kaplan, Norton [11].
} 
innovations and effective improvement of processes ${ }^{4}$. The perfection of simplification of processes becomes a modern phenomenon of our time, but nevertheless, only a few companies are focused on the basic innovation in styles and approaches of their own company management. Hamel [9] describes the basic innovations of management focused on innovations in the management process, including recommendations and procedures for the performance of everyday managerial work.

There were numerous approach models developed and successfully implemented into practice after a theoretical introduction, all with the aim to monitor and enhance performance. The $7 \mathrm{~S}$ Model describes 7 basic areas that have to be accepted by the managers in order to achieve the desired strategy. These 7 areas are all interrelated. Methods to enhance performance on the basis of potential improvement or narrow places optimization were developed. Lean management, KAIZEN and Lean Six Sigma are very popular with companies. In the environment of all these approaches and methods it is important to see the role of the manager as the main transferee of thoughts from top management to lower levels - without a full understanding of the company strategy throughout the company, the former cannot be successfully implemented. Thus, the managers should be seen as the center of interest of the soft factors ${ }^{5}$ of performance management. Also, we should not neglect the very important role of managers to build the company culture.

When referring to the area of personal management, it is important to focus on the quality of employees and managers and on ensuring a constant perfecting of management methods together with enhancing their skills and knowledge. According to Učeň [16] the method of the improvement potential is one of the basic methods of enhancing the performance of a business. Managers in the position of team or group leaders have to focus on both the management and the perfection of the work performance of their team or group. It is important to set a balance between orientation for short term and long term performance within the company's overall strategy.

\section{Changing management requirements ${ }^{6}$}

Many companies are starting to realize that their success is closely linked to a successful company performance management. One of the most important parts of performance management is the quality of human resources and their successful management.

In the environment of current modern management, a different role for managers has started to develop as well as new requirements for his/her character, skills and practices. Undoubtedly, managers are the most important link in the company and thus the quality of management is closely linked to their skills and abilities. Veber [17, p. 36] states, that now, more than in the past, the managers will have to find time to complete and develop their skills.

The basic prerequisite of a company's success is the fact that the managers have to set the direction. The traditional approaches to work tended to be more oriented towards the past than

\footnotetext{
4 One of the outputs of the Internationals Scientific Conference Performance of Organizations 2001 held in Poprad, Slovakia on 22nd and 23rd September 2011 was the statement, that the source of performance and its enhancement are namely the processes in the company.

5 Soft skills are very difficult to be measured but they currently represent very valued managerial abilities, just as leadership, motivation, ability to solve conflicts, communication and organization skills.

6 Within this article, all managing employees and people responsible for the operation of a part of a company (team, center, division) or a company as a whole are considered to be managers. Many other authors use the term leader instead of manager, but in the context of this article, these two are synonyms.
} 
the future. People were motivated to maintain customs and traditions of the company and that was what was hoped to be enough to keep the company going. In the quickly changing world, though, only those who are future-oriented will survive. This applies to companies as a whole as well. Only the company that actively searches for new opportunities and ways of work will prosper. [13, p. 130]

From the above statement, we may derive the conclusion that one of the important tasks for managers is to prepare the employees for the future, be it close or distant. In my opinion this is drawn from the strategic principle and controlling approach focused exclusively on the future. $^{7}$ A good manager is successful regardless of the environment he/she is working in and regardless of the level of organization structure he/she is on. The success of a manager is then linked namely to his/her personality - an individual strongly focused on personality is more probable to become a good manager. ${ }^{8}$

Our time is characterized by information over-feeding and the only way to be spotted in the information flood is to present original ideas. These original ideas should be mainly of managers on higher management levels who should not be afraid to make radical cuts or, in order to operate on the strategy, get the support throughout the company [5]. It is very important for me personally to remind you that the managers have to be able to work with the information effectively. At the same time it is important for the company that the managers are able to manage the system of meetings and organize only effective meetings that help improve team communication and cooperation- thus leading to better results. ${ }^{9}$ Every successful manager has to be effective and effectiveness can be (and has to be at the same time) learned. The Effectiveness has to be understood as a self-morale issue and the effectiveness target is considered automatic [6]. Managers have to go through a process of constant perfecting, be it in connection with the changing environment ${ }^{10}$, or in connection with the development of the company within the life-phases of it. They have to be able to constantly gain knowledge and skills and during their professional carrier they have to assimilate new working habits.

\section{The new role of managers}

With the changes in organization, that is becoming lean, flexible and learning, the role of managers is changing as well; the requirements of the owners or of the top managers to work with the lower managers also change. The development of individual managers is starting to be directed towards the development approach and managers are becoming more teachers and organizers than mere leaders. In relation to their subordinates, they act as coaches and help them understand the function of individual processes in the company and in solving the causes of problems within the company. The role of the manager in individual companies is different and depends mainly on the company overall strategy.

\footnotetext{
${ }^{7}$ Managers should not think about the past but mainly about the future. All current management theories emphasize the need for a strategic approach and future performance management.

${ }^{8}$ The personality of managers is underlined in many management models, namely in connection with natural authority.

9 Meetings represent a way for managers to get valuable feedback, and for the team member, it is a place for the exchange of information and experience. For more on effective meetings see Čempelová [4].

10 Here we have to mainly realize the important development in technologies, globalization issues and the related requirements on the knowledge of management methods, natural habits and customs of different cultures, language skills, competition pressure or new research results.
} 
Slater [15] describes the secret of the success of Jack Welch. ${ }^{11}$ Among other things, he states that it is important for managers to create an atmosphere in which employees are not afraid to express their opinion. Managers, according to Welch, should listen to people who create real value. Liker [12] describes the principles of the management model on which the famous Toyota Company is built. Leaders in this very successful business profess a unique approach and philosophy, which correspond to a set of principles of Toyota. A two-dimensional matrix line in Figure 1 helps to create an idea of what is different in the management of this company compared with others. Leaders can be controlled either through binding directives "top down", or by applying the 'bottom up' approach, which is characterized by the preoccupation of capturing the interest of people and encouraging their development so they can think independently and make decisions. Liker also lists 14 principles of management of the world's largest manufacturer, where he, among others, recommends that companies educate leaders enough to absolutely understand the work, live the philosophy of the company and teach it to the others. He further recommends companies to develop exceptional people and teams governed by the philosophy of the company.

\section{Leaders of the Toyota Company}

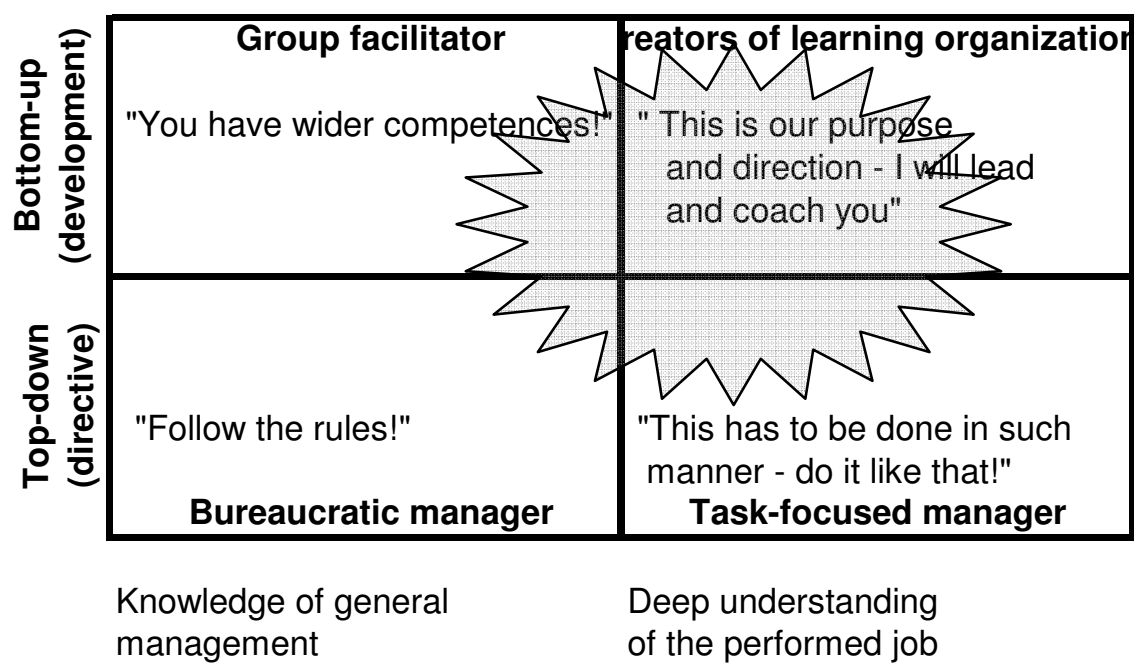

Fig. 1: A two-dimensional matrix of management in the Toyota Company

Source: [12, p. 231]

Managers today must behave particularly effectively, in the very important role of working with people and they should associate with very good soft skills which dominate contemporary managerial approaches of efficiency and performance. Skills and qualities of an effective manager must include in particular the role model for others, self-knowledge, continuing education $^{12}$, pleasure in change, awareness of reality, systemic thinking, good communication, art to be enthusiastic, and positive thinking [10, p. 24-29] .

\footnotetext{
11 Welche was the eighth director of General Electric.

12 In education, business managers can benefit from a wide range of subsidies from the European Social Fund, it is possible to obtain funding from various programs. The Operational Program Human Resources and Employment, which is aimed at reducing unemployment by active labor market policies, vocational training and has been allocated 1.84 billion euro. Operational Program Education for Competitiveness that focuses on human resources development through education in all its various forms has been allocated 1.82 billion euro. Operational Program Prague - Adaptability is aimed at increasing the competitiveness of Prague through enhancing the adaptability and performance of human resources and improving access to employment and the EU funds allocated 108.39 million euro to it.
} 
It is very important to remember that managers have to try to make the people they lead successful. This is linked to the principle that the most valuable assets of a company is in the people, their knowledge and skills. Nevertheless, it is equally important for the managers to have the trust of others as a key competence in the new global economy. While a high level of trust does not necessarily have the power to prevent bad decisions and bad strategy, a low level of trust is almost always the reason for the crash of a good strategy [2, p. 39].

\section{Requirement on expert knowledge of managers}

The areas of competence are generally distinguished by their four basic levels: professional competence (the knowledge of working practices and the possibilities to act within the company, etc.), methodical competence (the ability to acquire flexibly and effectively new knowledge and new working methods), social competence (the ability to build and maintain relationships, listening, tolerance), personal competence (self-reflection, positive approach to change, initiative, etc.). The Model of managerial competence is illustrated in Fig. 2.

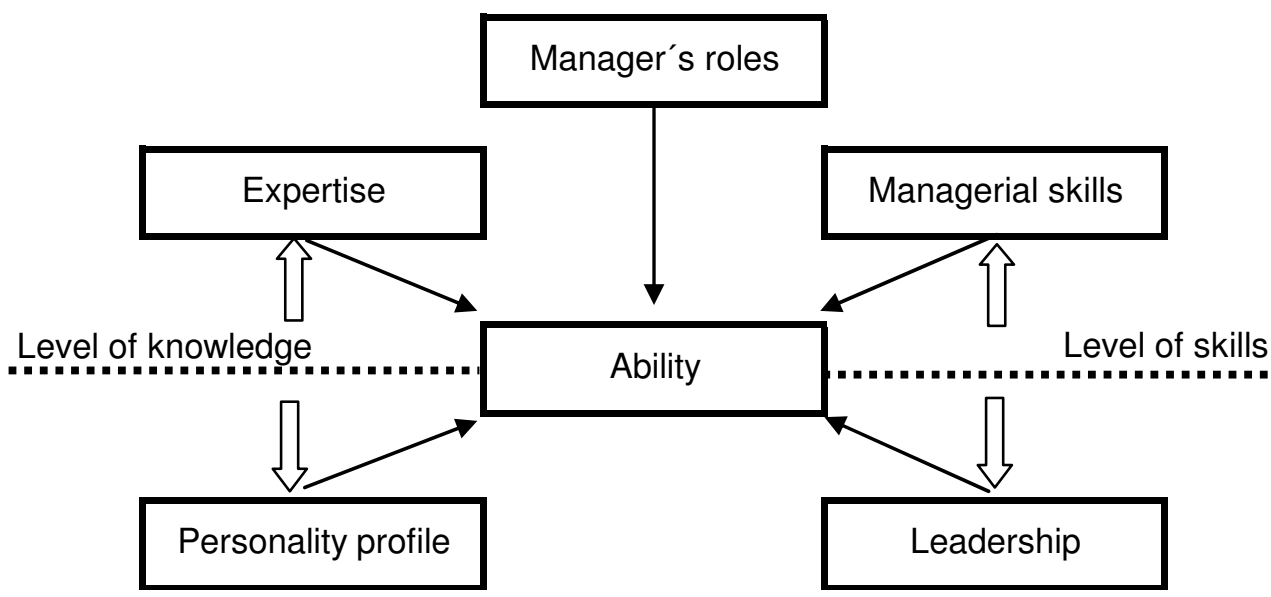

Fig. 2: Model of managerial competence

Source: $[14$, p. 360$]$

The model of the continuous training of managers within the support of the European Union is successfully applied in the practice of countless businesses, even those that would not consider education without financial assistance. In practice, the companies are most interested in soft skills from the group of management courses that roughly make up $70 \%$ of all requests for training. Companies are thus very much aware of the need for continuous training of their managers and their important role in the functioning of the enterprise.

I hold the opinion that the trend today is becoming an ever-increasing demand on the expertise of managers, be it related to the intellectual trend in management or in the relation to the areas in which managers are responsible ${ }^{13}$.

\footnotetext{
${ }^{13}$ If the manager is to execute the right decision, he/she must be thoroughly familiar with the area in which the decision is to be made. This of course is closely related to the fact that he/she needs to understand the area. It is not possible to only perform managerial roles and to improve managerial skills. It is very important for managers
} 


\section{Performance of individuals and teams}

If the management of a company is focused on performance related methods and approaches have to be implemented in line with the company strategy in the area of human resources, management should focus on the growth of quality in the employees [6]. This can be achieved through the growth of the capabilities and skills of managers, who must constantly think in line with corporate strategy. Within the concept of this understanding, we must not be limited to the performance curve of individuals during the day, but the performance curve over a longer period of time.

Performance management must be understood as a continuous process within which emphasis needs to be placed on achieving a permanent improvement of performance and a continuous development of skills and of the overall competence. Performance management in the course of a year is illustrated in Fig. 3 .

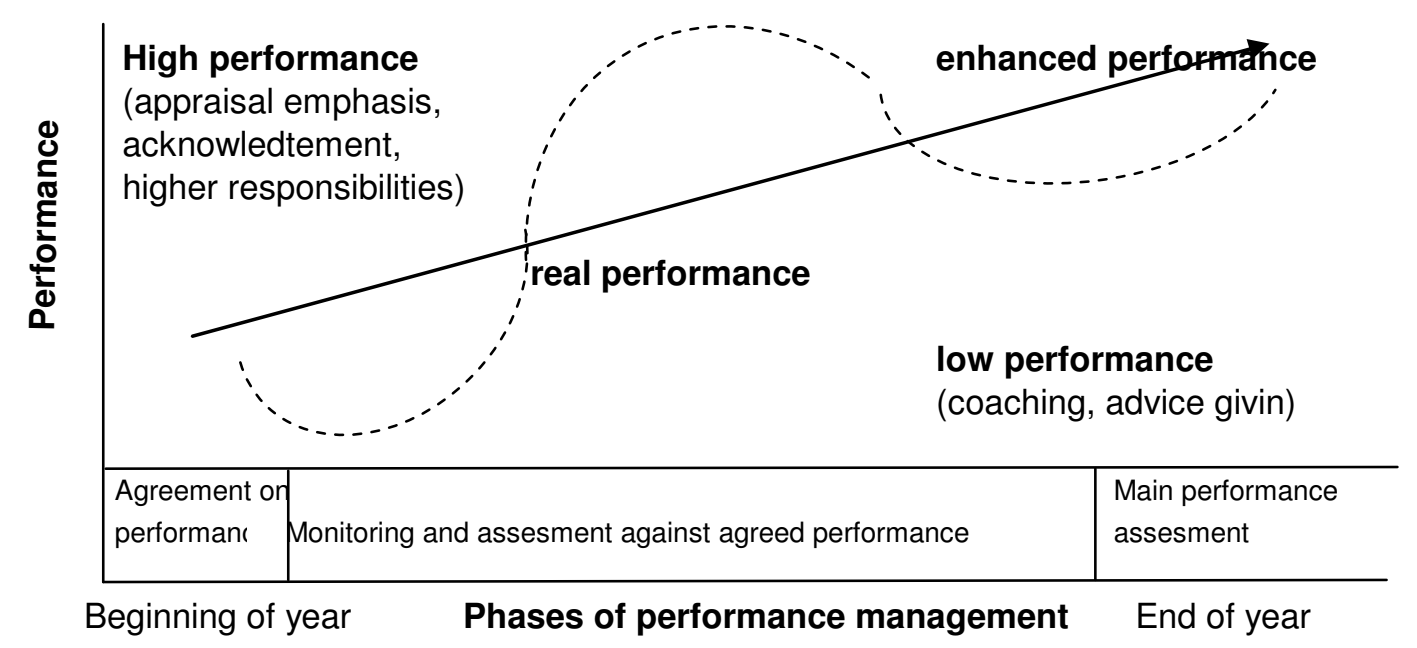

Fig. 3: Performance management

Source: [1, p. 248]

It is undoubtedly an important object of interest to assess whether the manager's performance evaluation should be subject to the evaluation of personal performance and team performance which he controls. In practice it would probably be applied according to predefined rules, and both the criteria would be assessed separately for each individual case. For a business, the performance of the whole team the manager manages is substantial. Nevertheless, the team performance is closely linked to the quality, abilities and skills of its manager.

\section{Management of work performance of an individual}

The new concept of performance management is one of the most important benefits in the sphere of management in recent years. It began to form in the late 80 s of the last century based on the awareness of the need to achieve a more consistent and integrated approach to managing and rewarding work performance. Performance management has emerged like a phoenix from the already well-established, but somewhat discredited, system of merit rating

to constantly improve in the field in which they perform their management function and to possess a deep understanding of the work performed. 
and management by objectives ${ }^{14}$. The concept of performance management, the aim of which is a much broader, more complex and more natural management process, also absorbed much of what has been created in recent years in the area of employee appraisal. [1, p. 238]

If we accept Drucker's [7] idea that the performance ability of a company is defined by people, and business performance is, in fact, determined by the human resources productivity, then I have to say that the individual employees are the most important part of the business and performance management of individuals must be given increased attention. The quality of the management of their performance is proportionally dependent on the success of the leader of the team, into which a particular individual is functionally or organizationally located and is in direct relation to the management performance of the team. From this we can easily conclude that the greatest emphasis must be placed on the leaders of the teams who are able to indicate the direction of the team, manage their efficiency and improve performance in relation to its desired level.

\section{Management of work performance of a team}

Performance management of team work is based on the principle that the basic units of the learning organization are working teams. ${ }^{15}$ In this case, however, we cannot be limited to the idea that you can only manage what you can also measure in reality. Team performance is certainly a measurable unit, but even here there is a need to monitor heavily measurable merits such as loyalty, commitment, willingness, the ability to cooperate, relationships and development. These indicators from the field of soft skills significantly affect the overall team performance, and very often influence future performance.

Plamínek [13] presents six characteristics of teams and defines them in relation to his practice:

- shared goals

- good communication

- shared paths

- roles division

- quality relationships

- development possibilities.

He stresses that one of the roles the team can attain is the natural leader ${ }^{16}$. He does not define a leader as one of the conditions of team success, but as a potential help in the creation of team success. According to Plamínek, the typical combination of two somewhat contradictory tendencies is important for the team: sharing (which is dominating especially in the

\footnotetext{
14 The aim of management by objectives (MBO) is to link all sub-teams to build and consequently to perform a single plan, consisting of individual goals. Participating teams are not only involved in the preparation and establishment of these goals, but also decide on the manner and methods by which these goals are being attained. The related payroll system must not be neglected - the remuneration is directly linked to predetermined performance targets.

15 In practice the absence of team work is compensated by pressure on higher performance.

16 While managers must focus on the final results, leaders must focus on the vision and setting the course. A good manager is a driving force behind the processes and performance, while the leader becomes the navigator, the catalyst and driving force for change and progress by the ability to best formulate and express the inner needs and expectations of colleagues, associates and organizations. While the leader provides an overall picture and vision accepted and shared by all the followers, the manager completes the detail. While the manager manages people, the leader leads [12, p. 83].
} 
substantial and procedural area) and diversity (especially respected in the human and relational area).

In my opinion the work performance of a team is closely dependent on the role of the team leader and performance management of individual team members. If there is pressure from the leader of the team or the company management to improve the performance of individuals, it is not guaranteed that the activity will automatically increase the performance of the team and thereby increase business performance. It is undoubtedly necessary to pay attention to other factors that affect team performance improvement, especially the bond between team members and the relationship to the team leader. ${ }^{17}$ If the team leader has a distinctive personality, the other team members may show their team's effectiveness through the interaction between team members and the leader. The willingness to cooperate with the leading personality is at least multiplied and at the best can even augment the team's performance.

The managers of the individual teams are well aware of the existence of differences in the performance of individual team members. Covey [3, pg. 32] says that the performance of individuals may be monitored on the individual levels of performance. $20 \%$ of the employees have a low performance, $60 \%$ of the employees give a medium performance and the remaining $20 \%$ of the employees deliver a high performance. Within the $60 \%$ of medium performance employees there are individuals who could contribute more provided that they knew how. The greatest opportunity for the managers of each team is the chance to move the center of the performance curve to the right. For this purpose, managers must find exceptional individuals in their teams who can share their experience with other team members to achieve a better overall performance of the team. At the same time managers must constantly ask team members to improve their performance on any project.

\section{Performance assessment ${ }^{18}$}

It is very difficult to establish clear rules for assessing the performance of individual managers and teams where the majority of team activities do not correspond with the time period in which we can see the benefits of achieved performance. It is nevertheless important to attribute a certain weight of importance when evaluating the performance to these activities, although we are not able to objectively measure the accuracy of specific outputs. It is important to design the entire evaluation process within the framework of the predetermined expected performance. Unless we specify in advance what is expected from a manager or a team member, it is impossible to assess the actual performance when we cannot compare this with the expected performance.

\footnotetext{
17 The team leader with natural authority can lead his/her team more effectively than the leader with enforced authority. In this case we will understand efficiency as a team performance in terms of both quantity and quality of innovation, as well as staff morale.

18 If the company establishes the rules of performance of individuals and teams, the importance of precision and performance evaluation settings must not be overlooked. Usually a period of one year is set, but in practice we may observe cases, when in connection with a shorter frequency employee evaluation system, which are measured against performance in this reporting period, that can be semi-annual or even quarterly.
} 


\section{Barriers in implementation of performance management ${ }^{19}$}

Although performance approaches are generally considered as the most basic and the inevitable approaches to the effective management of enterprises, in practice managers might face various obstacles to their implementation. In the following points, I describe my own summary of performance management:

- Incorrectly interpreted strategy of the performance approach. In practice it is very often manifested by the staff as a strategy to reduce costs without a detailed explanation to all employees. In the extreme case we can get the opposite effect, i.e. reduced performance of individual employees, thus reducing the performance of their team and the whole enterprise. The incorrectly interpreted strategy of the performance approach can paradoxically lead to a reduction in corporate performance.

- Lack of necessary knowledge and skills, when managers are driven to improve their managerial skills in the concept of professional competence, the management sometimes does not realize the basic shortcomings of managers in this area. Unfortunately, it is not proven by practice that all managers are able to use various forms of training and courses to learn these skills, and although we argue that managers are not born but must be trained gradually, it is equally true that not every manager who learns managerial skills and techniques is able to acquire them well enough to be a good manager.

- Lack of effective thinking of managers is a significant handicap when their effectiveness is seen as an implication in the performing management activities. Effective thinking is related to economic thinking, which should be included in the overall thinking of each manager.

- Lack of top management support is a key milestone in the implementation of a strategy to increase business performance. If the senior leadership does not create the necessary background for these purposes, any efforts of individual managers are seriously weakened.

- Absence of a natural leader. A natural leader is always able to quickly and efficiently bring the desired improvements in performance to his/her team; in some cases the leader him/herself can contribute to a faster enhancement of performance than was originally expected.

- Lack of confidence is a hidden variable in the formula defining the organization's success. Although the company has an excellent strategy for increasing the performance and has capable managers with the knowledge of methods and approaches of performance management and soft skills to meet the strategy, low confidence in the company can cause a decrease in the expected outcome. Conversely high confidence can result in an even bigger increase of the expected result.

\section{Set of my own recommendations for effective performance management with integrated approach}

Companies must realize that using only partial applications of approaches without other methods and practices will not put these approaches into practice successfully. It must always be borne in mind that the hard factors must be complemented by soft factors such as financial

\footnotetext{
19 Barriers were evaluated on the basis of previous theoretical work and also based on practical experience. I myself have used performance management in practice for more than 7 years. In practice one must devote more than 7 years to the field of performance management.
} 
risk and, the factors of flexibility and leanness ${ }^{20}$. This concept is applicable for enterprises putting equal weight to the importance of all these factors, and only in such a case can they successfully meet their set objectives.

If it is part of the business strategy to apply the performance approach ${ }^{21}$, the importance of soft factors should never be overlooked, as well as the importance of managers as the main links between top management and employees of the company. Only accomplished managers are perfectly able to lead their teams through performance management and performance of individuals within the team, and the management of performance of the team is involved in improving the performance of the enterprise. For effective managers it is appropriate to focus on indicators that are under control and are most likely to produce the desired results. It must have the following indicators under constant monitoring and the evaluation of improving the performance because it is very closely connected with the monitoring of key indicators. Managers often commit an error when a huge goal is announced and they wait in the comfort of their office and expect it to be met [3]. However, if they never ask about the target, their team will not be interested in it and will most likely devote their time to day-to-day activities.

For the purposes of effective management it is therefore important for the enterprise that the management focuses tremendous efforts in connection with the selection of quality-minded and effective managers who can lead the most powerful and effective teams. They should not only pay attention to the selection of managers, but as well to the continuous education and improvement of their existing managers ${ }^{22}$.

As pointed out above, it is not possible to strictly separate the functions and methods of general and personal management which does not show any clear guidelines. For businesses, one of the possible recommendations is not to focus on complex factors of corporate management, but to divide them into separate parts according to the specific needs of enterprise and consequently evaluate them so that each individual part is used within the system of corporate management in the same proportion. Only then can a balanced management system be attained. In practice it is not possible to set aside performance management as a separate managerial role, companies should accept this approach as an absolute part of corporate strategy and corporate governance and as such it should be part of the evaluation factors of this approach.

\section{Conclusion}

In this article I have described the theoretical basis of current management approaches in business management which are closely linked to personal management. In all the current approaches applied in companies around the world it is clear that now the greatest emphasis is put on working with employees, who are considered to be the biggest asset. For the

\footnotetext{
20 Slenderness factors are special factors which in partly belong to the hard factors (methods and practices of lean management) and partly to the soft factors (lean thinking), and that is why I identified them independently. This is mainly because the methods of flexibility and slenderness are currently highly given attention and are placed in the center of interest of management of most enterprises.

21 Theoretically, we could consider that the performance approach is an automatic part of the management of each company, but this practice is not always fulfilled. Common strategies are only a part of the performance approach or a separate cost-cutting strategy and lean management, which are completely different approaches from the performance approach.

22 As a part of many expert managerial courses there are numerous managerial games and practical examples and exercises presented where the managers are actively participating on the course and thus gain very valuable new experience for their further development in the field.
} 
purposes of quality work with employees it is important to make great efforts to work with managers to improve their knowledge, skills and thereby influence the management of the staff and get the most from their knowledge and skills. If we accept the idea that businesses are presently struggling to focus on improving performance and efficiency, then through effective work with employees, performance management of individuals and teams can be highly effective in achieving their goals. Particular leaders of these teams are of assistance and they are expected to behave efficiently. They will think leniently, will have mastered the soft skills and ideally will be more a leader than a manager. At the same time the importance of natural authority and trust must not be neglected, for they positively multiply the success of performance of the team and the entire enterprise. Apart from the theoretical grounds of performance management, I have described my own conclusions from my long-term managerial practice in the article, applying the methods of observation. I have defined the basic barriers which I believe may represent a general barrier in the implementation of performance management in businesses. At the same time, I have defined my own set of recommendations where I recommend businesses to focus on the selection of accomplished managers, who will be capable leaders of their accomplished teams. Naturally this process must not end with the mere selection of managers, but must be continued through their improvement in both the area of managerial skills and of their professional knowledge along with constant pressure to enhance their performance.

\section{Literature:}

[1] ARMSTRONG, M. Personální management, Praha: Grada , 1999, ISBN 80-7169-614-5

[2] COVEY S.M. Di̊věra: jediná věc, která dokáže změnit vše. Praha: Management Press, 2009, ISBN 978-80-7261-176-8

[3] COVEY S.M. Jak dosahovat předvídatelných výsledků v nepředvídatelných časech. Praha: Management Press, 2010, ISBN 978-80-7261-206-2

[4] ČEMPELOVÁ, Z. Moderní řizení 6/2011, Praha, 2011, ISSN 0026-8720

[5] DRÁB, R. Moderní řizení 10/2010, Praha: Economia, ISSN 0026-8720

[6] DRUCKER, P. Efektivní vedoucí. Praha: Management Press, 2008, ISBN 978-807261-189-8

[7] DRUCKER, P. Drucker na každý den. Praha: Management Press, 2009, ISBN 97880-7261-140-9

[8] GROVE, A.S., Řízení orientované na výkon. Praha: Management Press, 1998, ISBN 80-85943-60-3

[9] HAMEL, G., BREEN, G. Budoucnost managementu. Praha, Management Press, 2008, ISBN 978-80-7261-188-1

[10] KAMP, D. Manažer 21. století, Praha: Grada, 2000, ISBN 80-247-0005-0

[11] KAPLAN, R.S., NORTON, D.P. Balanced Scorecard, Praha: Management Press, 2000, ISBN 978-80-7261-177-5

[12] LIKER, J.K. Tak to délá Toyota. Praha: Management Press, 2010, ISBN 978-80-7261173-7

[13] PLAMÍNEK, J. Vedení lidí, týmů a firem. 3. vyd. Grada , 2008, ISBN 978-80-2472448-5

[14] ̌̌ZÁČC, J. Moderní management. 1. vyd. Praha: Computer Press, 2009, ISBN 97880-251-1959-4

[15] SLATER, R. 31 Tajemství úspěchu Jacka Welche. Praha: Management Press, 2007, ISBN 978-80-7261-000-6

[16] UČEŇ, P. Zvyšování výkonnosti firmy na bázi potenciálu zlepšení. 1. vyd. Praha: Grada, 2008, ISBN 978-80-247-2472-0 
[17] VEBER, J. Management - Základy, moderní manažerské př́stupy, výkonnost a prosperita. 2. vyd. Praha: Management Press, 2008, ISBN 978-80-7261-200-0

JEL M12

Ing. Dagmar Burdová, MBA

externí doktorand

Obchodně podnikatelská fakulta v Karviné

Slezská univerzita v Opavě

Univerzitní náměstí 1934/3, Karviná

burdova.dagmar@seznam.cz 